\title{
Macroeconomic Factors and Public Debt: Empirical Evidence from Jordan
}

\author{
Ali Mustafa Al-Qudah \\ Department of Finance and Business Economics \\ Faculty of Economics and Administrative Sciences \\ Al Al-Bayt University \\ Mafraq, Jordan
}

\begin{abstract}
This study aims to examine the impact of budget deficit, real GDP growth, unemployment rate and government current expenditure on public debt in Jordan for the period (1992-2017), the study used autoregressive distributive lag (ARDL) approach to examine the study hypotheses. ARDL bound test and co-integration proven that there is a long run relationship exists between budget deficit, real GDP growth, unemployment rate, government current expenditure and public debt in Jordan. The ARDL long run coefficients show that Real GDP growth has a negative and significant impact on public debt while budget deficit and unemployment rate have a positive and significant impact on public debt, but government current expenditure has a positive and not significant impact on public debt in Jordan. In the short run the empirical results show that the first difference of budget deficit and government current expenditure have a positive and significant impact on public debt in Jordan, and the first difference and lag (1) of unemployment has a positive and significant impact on public debt in Jordan. The (CUSUM) stability test shows that the public debt (PD) estimated model is stable.
\end{abstract}

Keywords: Public Debt, budget deficit, Real GDP growth, Government current expenditure, ARDL, Jordan.

\section{Introduction}

Both developed and developing countries have witnessed a continuous increase in public debt throughout their history due to increased state intervention in economic and social life resulting in more public spending. In times of economic recession, national income declines, and tax revenues drop which making public spending larger than public revenues and leading to an increase in the public budget deficit and thus an increase in public debt. Public debt may be the good thing for the state or the great evil of the state. Public debt can help developing countries by providing the necessary funds to invest in infrastructure projects and social projects, facilitating tax settlement and counter-fiscal policies of the economic cycle (Gill \& Pinto, 2005) However, external public debt can affect positively and significantly the possibility of the debtor's inability to pay its debts. Thus, when creditors are unsure of the debtor's ability to pay, this could lead to the beginning of the liquidity crisis of the debtor state (Sturzenegger, 2002).

The public debt crisis of countries around the world has consistently shown different negative consequences in economic, social and political life, where insolvent states can't perform their main functions efficiently in the provision of public goods and services. In addition, the failure of the state to pay its debts may result in rising inflation, devaluation of the national currency, banking crises, loss of private savings, increasing poverty in society, declining confidence in the government and a decline in the country's credit rating. Public expenditure on education, health, sanitation and public goods such as roads, highways and bridges is a moral responsibility of the government, and investment in these areas is huge and this large spending of the government strengthens the confidence in the economy, which encourages private investment, Often emerging and developing countries resort to borrow to finance these projects because of a gap between public revenues and public expenditures, which leads to the accumulation of public debt, but the development and social incentives of the state is large and therefore any country has aspirations for growth and related development incentives must eventually rise in the balance of public debt and that the inability of these investments to generate revenues more than expenditures will increase the public debt (Rogoff and Reinhart, 2008).Jordan is experiencing an ever-increasing public debt, which exceeds $90 \%$ of GDP in 2017. The country's continued borrowing will affect economic growth, aggregate demand and domestic savings. This high level of public debt poses major challenges to the Jordanian economy. The Jordanian government is trying to limit the increase in public debt and work to reduce it by using a contractionary fiscal policy and improving the efficiency of the tax system to increase its revenues and reduce the budget deficit and thus limit the expansion of public debt depending on the above problem the objective of this study is to examine the public debt macroeconomic determinants in Jordan for the period 1992-2017, the research finding and recommendations may help the policy makers in Jordan to stop expansion 
in public debt and attempt to reduce it to safe level, and may help scholars to further research on public debt determinants and may be used as a reference point on further studies on public debt in developing countries. The study consists of five sections: Section one introduction, section two literature review, section three data and methodology, section four empirical results and section five conclusions.

\section{Literature Review:}

There are many studies on the effect of public debt on economic factors such as GDP, inflation, interest rate, unemployment, etc. However, the study of the impact of economic factors on public debt is one of the topics that need further research because it is still to some extent a new topic. In the following some of the studies that deal with the impact of economic and political variables on public debt. Waheed (2017) examined the macroeconomic determinants of external debt, the macroeconomic determinants represented by (real GDP growth, current account balance share of GDP, general government expenditure share of GDP, general government revenue share of GDP, foreign exchange reserves, gross fixed capital formation share of GDP and inflation rate) for 12 oil and gas exporting countries and 12 oil and importing countries for the period 2004- 2013, the study used panel data analysis, the results show that economic growth, foreign exchange reserves, government revenue, price of oil and capital formation are important determinants in reducing external debt for oil and gas exporting countries, while current account, government expenditure and inflation increasing external debt for exporting countries for oil and gas. and the results show that economic growth, government revenue are important determinants in reducing external debt for oil and gas importing countries, while trade deficit, oil price, interest payment on external debt, FDI and domestic investment increasing external debt for oil and gas importing countries.

Gargouri and Ksantini (2016) examined the determinants of public debt in 12 European countries for the period 20002014. They used the correlated panels corrected standard errors model to examine their study hypotheses. The study found that imports, military spending and non-performing bank debt had a positive impact on the public debt, while the study found that GDP growth and bank liquid reserves had a negative effect on Public debt. Pirtea, Nicolescu and Mota (2013) examined the macroeconomic factors influence public debt in Romania for the period 2000Q1 and 2011Q1, the regression analysis results proven that budget surplus, real GDP growth and FDI have a negative impact on public debt while exchange rate against dollar, real interest rate have a positive and significant impact on public debt, the openness of the economy has a negative and not significant impact. Swamy,(2015) examined the government debt macroeconomics determinants for advanced economies, emerging economies, developing economies and OECD economies for the period 1980-2009, he used fixed effect panel generalized method of moment (GMM) regressions for identifying the determinants of government debt in the full sample, the regression results indicate that real GDP growth, foreign direct investment (FDI), inflation, government expenditure, population growth have a negative and significant impact on government debt, while final consumption expenditure, gross fixed capital formation and trade openness have a positive and significant impact on government debt. Bittencourt (2013) examined the main determinants of government external debt in nine South American countries that re-democratized in the last thirty years or so, for the period 1970-2007. panel (time-series) data analyses ( Pooled OLS, Fixed effect, Fixed effect with Instrumental Variables, DIF-GMM and SYS-GMM estimators) used to indicate the determinants of government external debt. the results suggest that economic growth has a negative and significant impact on debt. inflation, inequality and constraints on the executive do not present the expected impact on government and external debt. conclusions are suggested to improve economic growth at least, for keeping debt under control.

Mah, Mukkudem-Petersen, Miruka and Petersen (2013), examined the impact of government expenditure on public debt in Greece using the vector correction model and granger causality model for the period 1976 to 2011 .They found that government expenditure has a positive and significant impact on public debt in Greece. Sinha, Arora and Bansal (2011) analyzed the impact of current account balance, the expenditures of the central government, long term interest rate, the rate of growth of real GDP, inflation, foreign direct investment and the number of people per square $\mathrm{km}$ on the public debt in middle and high income countries, a panel data for 31 countries used, the period 1993-2008 for high income countries and 1980-2008 for middle income countries, they used cross section fixed effects model and cross section random effects model to examine the study hypotheses, they find that GDP growth rate, central government expenditure, education expenditure, and current account balance impact the public debt for both high income and middle income countries, while they find that FDI and inflation rate have no impact on public debt for high countries but have an impact on public debt in middle income countries. And they find that population density has no impact on public debt for both middle and high income countries.

A review of previous studies found that there were few studies on the determinants of public debt. The reviewed studies used different techniques ranging from multiple linear regression and analysis of panel data using a fixed effects model and a random effect model. 
Previous studies have found that the budget surplus, the real growth rate of GDP, foreign direct investment, public spending and population growth have a negative impact on public debt, while the exchange rate, real interest rate, economic openness and capital formation have positive effects on public debt. The current study is an extend to the previous studies, to examine the impact of public budget deficit, real GDP growth, government current expenditure and unemployment rate on public debt in Jordan for the period 1992-2017. The current study contributed in the literature through examine new macroeconomic variables budget deficit, unemployment rate and introducing a proof on the determinants of public debt from Jordan as a developing country. The study used ARDL approach to examine the public debt macroeconomic determinants in Jordan.

\section{Data and Methodology:}

\subsection{The Data}

The current study used annually time series data for the period (1992-2017) and the data related to public debt, budget deficit, real GDP growth and government current expenditure obtained from the Central Bank of Jordan database (Central Bank of Jordan, 2018), while the data related to unemployment rate from World Bank database(World Bank, 2018).

\subsection{Methodology}

Previous studies have used different techniques to test the relationship between macroeconomic variables and public debt such as multiple linear regression and panel data analysis by using the fixed effects model and the random effects model, this study used autoregressive distributive lag ARDL approach to examine the macroeconomics determinants of public debt in Jordan. This study used ARDL approach because it can be applied for all time series, regardless the degree of integration I(0) Or I(1), and if they are a combination of of I(0) and I(1) but it can't be applied if one of time series is stationary of I(2), (Pesaran and Shin, 1999, and Pesaran et al. 2001). in addition ARDL approach is considered as a powerful method for small samples (Pesaran and Pesaran, 2002). Also, ARDL approach output gives the short-run dynamics and long run relationship of the considered variables and it has only one cointegration equation. (Ahmad , Ahmad, Mushtaq and Nadeem, 2016; Nkoro and Kelvin Uko, 2016). Research question: How do budget deficit, real GDP growth , government current expenditure and unemployment rate impact on public debt in Jordan?

\subsubsection{The Model Specification}

The model includes public debt as a ratio of GDP, budget deficit as a ratio of GDP, real GDP growth, government current expenditure as a percentage of GDP and unemployment rate.

$\mathrm{PD}=\beta 0+\beta 1 \mathrm{BD}_{\mathrm{t}}+\beta 2 \mathrm{RGDPG}_{\mathrm{t}}+\beta 3 \mathrm{GS}_{\mathrm{t}}+\beta 4 \mathrm{UNE}_{\mathrm{t}}+\mathrm{U}_{\mathrm{tn}}$

where PD is public debt the dependent variable, the independent variables are, BD balance budget, RGDPG real GDP growth, GS gross expenditure and UNE unemployment rate , $U$ is the error term, $\beta 0$ is the constant, $\beta 1, \beta 2, \beta 3, \beta 4$, are parameters , $\mathrm{t}$ is the time.

The unrestricted ARDL model takes the following form:

$$
\begin{gathered}
\Delta P D t=\beta 0+\sum_{i=0}^{n} \beta_{1} \Delta P D_{t-i}+\sum_{i=0}^{n} \beta_{2} \Delta B D_{t-i}+\sum_{i=0}^{n} \beta_{3} \Delta G D P G_{t-i}+\sum_{i=0}^{n} \beta_{4} \Delta U N E_{t-i}+\sum_{i=0}^{n} \beta_{5} \Delta G S_{t-i}+\beta_{6} P D_{t-1} \\
+\beta_{7} B D_{t-1}+\beta_{8} G D P G_{t-1}+\beta_{9} U N E_{t-1}+\beta_{10} G S_{t-1}+U t \ldots \ldots(2)
\end{gathered}
$$

where PD is public debt the dependent variable, the independent variables are, BD budget deficit, RGDPG real GDP growth, GS government current expenditure and UNE unemployment rate, $U$ is the error term, $\beta 0$ is the constant, the expressions with the summation sign $(\beta 1, \beta 2, \beta 3, \beta 4, \beta 5$, , ) represents short run dynamics of the model. The expressions $(\beta 6, \beta 7, \beta 8, \beta 9, \beta 10$,$) represents the long run relationship, U$ is the error term, $t$ is the time, ARDL approach includes two-steps for estimating long-run relationship (Pesaran et al., 2001): the first step is to verify a long-run relationship between all variables in the model by estimating unrestricted ARDL depending on that bound test estimated then we compare the F-statistics of the bound test results with the upper critical value of bound (Pesaran) test. The second step is to estimate the long-run and cointegration by using restricted (cointegration) ARDL. The second step applied if the first step shows that there is a long run relationship between model variables (Narayan et al., 2005).

\subsubsection{Study Variables}

\subsection{2,1 Dependent Variable}

public debt (PD): equals public debt as a ratio of GDP. the dependent variable public debt to GDP was used by Barro (1987), Ziesemer (2005) Martin (2004), Waheed (2017), Mah, Mukkudem-Petersen, Miruka and Petersen (2013), 
Sinha, Arora and Bansal (2011), Swamy,(2015), Bittencourt (2013) and Gargouri and Ksantini (2016). 3.2.2.2 Independent Variables:budget Deficit (BD): Difference between total revenue and total expenditureas a ratio of GDP. Real GDP growth (GDPG): (RGDP2-RGDP1)/RGDP1. Used by Waheed (2017), Mah, Mukkudem-Petersen, Miruka and Petersen (2013), Sinha, Arora and Bansal (2011), Swamy,(2015), Bittencourt (2013) and Gargouri and Ksantini (2016). Government current expenditure (GE): equals government current expenditure as a ratio of GDP. Used by Waheed (2017), Mah, Mukkudem-Petersen, Miruka and Petersen (2013). Unemployment rate (UNE): equals unemployment rate.

\subsubsection{Study Objectives:}

The study aims to achieve the following objectives

1- Examine the impact of budget deficit on the public debt in Jordan.

2- Examine the impact of real GDP growth on the public debt in Jordan.

3- Examine the impact of government current expenditure on the public debt in Jordan.

4- Examine the impact of unemployment rate on the public debt in Jordan.

\subsubsection{Study Hypothesis:}

The study examines the following null hypotheses.

H01: There is no significant impact of budget deficit on the public debt in Jordan.

H02: There is no significant impact of real GDP growth on the public debt in Jordan.

H03: There is no significant impact of government current expenditure on the public debt in Jordan.

H04: There is no significant impact of unemployment rate on the public debt in Jordan.

\section{Empirical Results and Analysis}

\subsection{Unit Root Test Results}

ARDL approach can be used if all the time series are stationary at level $\mathrm{I}(0)$ or if all the time series are stationary at level I(1) and if they are a combination of $\mathrm{I}(0)$ and $\mathrm{I}(1)$ but it can't be used if one of the time series is stationary at $\mathrm{I}(2)$ (Pesaran and Pesaran, 1997; Pesaran et al., 2001) . so to verify that we use The Augmented Dickey Fuller test (ADF) used to test the stability for the time series of the study variables public debt (PD) budget deficit (BD), real GDP growth (GDPG), government expenditure (GS) and unemployment rate (UNE). From Table (1) the results of the Augmented Dickey Fuller (ADF) unit root test, we find that public debt (PD) and budget deficit (BD) are stationary at first difference while GDP, UNE and GS are stationary at first difference I(1). In the light of the unit root test results which shows all time series are stationary at I (0) and I (1) we can apply ARDL to examine the relationship between variables.

Table 1: Augmented Dickey Fuller (ADF) Unit Root Test

\begin{tabular}{|l|l|l|l|l|l|}
\hline Variable & $\begin{array}{l}\text { Calculated ADF } \\
\text { Statistics }\end{array}$ & $\begin{array}{l}5 \% \text { ADF Critical } \\
\text { Value }\end{array}$ & Probability & $\begin{array}{l}\text { Order } \\
\text { Integration }\end{array}$ & $\begin{array}{l}\text { of } \\
\text { Stationary/ }\end{array}$ \\
\hline PD & -2.31465 & -1.95502 & 0.0227 & $\mathrm{I}(0)$ & Stationary \\
\hline BD & -2.67103 & -1.95502 & 0.0098 & $\mathrm{I}(0)$ & Stationary \\
\hline GDPG & -1.05104 & -1.95568 & 0.2561 & $\mathrm{I}(0)$ & Not stationary \\
\hline UNE & -1.44765 & -1.95502 & 0.1345 & $\mathrm{I}(0)$ & Not stationary \\
\hline GS & 2.476763 & -1.95502 & 0.9953 & $\mathrm{I}(0)$ & Not stationary \\
\hline PD & -4.08872 & -1.95568 & 0.0003 & $\mathrm{I}(1)$ & Stationary \\
\hline BD & -4.12068 & -1.9572 & 0.0003 & $\mathrm{I}(1)$ & Stationary \\
\hline GDPG & -9.72012 & -1.95568 & 0.0000 & $\mathrm{I}(1)$ & Stationary \\
\hline UNE & -3.21281 & -1.95568 & 0.0025 & $\mathrm{I}(1)$ & Stationary \\
\hline GS & -2.82328 & -1.95568 & 0.0068 & $\mathrm{I}(1)$ & Stationary \\
\hline
\end{tabular}

\subsection{Empirical Results and Discussion:}

To use ARDL approach, we must first test the existence of a long-run relationship between the study variables. To verify this, we estimate the unrestricted ARDL model depending on the output of that we estimate the ARDL bound test and compare the $\mathrm{F}$ statistics value with upper bound critical value if the $\mathrm{F}$ statistics value is greater than the value of upper bound critical value we reject the null hypothesis that states no long-run relationship exist between variables and accept the alternative hypothesis that states there is a long-run relationship between variables. if the long-run relationship exist, we estimate the restricted ARDL(Pesaran et al., 2001). 


\subsection{ARDL Bound test}

The hypothesis of the bound test is:

Ho: No long run relationship exist between variables.

$\mathrm{H} 1$ : There is a long run relationship exist between variables.

we estimate the ARDL bound test and we compare the F-statistics with the critical value tabulated by Pesaran and Pesaran (1997) or Pesaran et al. (2001) . from Table (2)the F-Statistics value (5.041661) is greater than the upper bound (Pesaran) value (3.49) at 5\%, so we can reject the null hypothesis that states no long run relationship exist between variables and accept the alternative hypothesis that states there is a long run relationship exist between variables. so this result proven that the variables have a long run relationship.

Table (2) ARDL Bound Test

\begin{tabular}{|lll|}
\hline Test Statistic & Value & $\mathrm{K}$ \\
\hline F-statistic & 5.041661 & 4 \\
\hline Critical Value Bounds & & I1 Bound \\
\hline Significance & I0 Bound & 3.09 \\
\hline $10 \%$ & 2.2 & 3.49 \\
$5 \%$ & 2.56 & 3.87 \\
$2.50 \%$ & 2.88 & 4.37 \\
$1 \%$ & 3.29 & \\
\hline
\end{tabular}

\subsection{ARDL Long Run Coefficients Results}

The results of the ARDL bound test proved that there is a long-run relationship between the variables of the model, as a second step, we can estimate ARDL cointegration and long-run, the results of the estimated long run coefficients are listed in Table (3).

Table (3)ARDL long-run Dependent variable PD

\begin{tabular}{|lllll|}
\hline Variable & Coefficient & Std. Error & t-Statistic & Prob. \\
\hline BD & 3.25598 & 1.726361 & 1.88603 & 0.0818 \\
GDPG & -4.24491 & 0.726204 & -5.84534 & 0.0001 \\
UNE & 12.71306 & 4.16495 & 3.052391 & 0.0093 \\
GS & 12.03754 & 10.51921 & 1.144339 & 0.2731 \\
C & -1.10611 & 0.96802 & -1.14266 & 0.2738 \\
\hline
\end{tabular}

1. From Table (3) the budget deficit (BD) has a positive and significant impact on public debt at 10 percent level with coefficient value of (3.25598) this means a 1 unit increase in budget deficit holding the other factors constant will increase public debt by (3.25598) units this is due to that the increase in the budget deficit leads to an increase in the public debt as well as the large deficit in the public budget increases the public debt ratio of GDP, in addition public debt has more interest payments, which increases the financial burden on the state and the national economy. The deficit in the public budget is a major element in government borrowing, where the government tends to borrow to bridge the deficit between public expenditure and revenues listed in the public budget. So budget deficit determines the amount of government borrowing. If the government is able to cover government expenditures from government revenues, it will have few reasons for borrowing. There are many economists confirmed the importance of the budget deficit in increasing public debt such as Dornbusch and Fisher (1990), Gordon (2003).

2.Real GDP growth (GDPG) has a negative and significant impact on public debt at 0.0001 percent level with coefficient value of (-4.24491) this means a 1 unit increase in Real GDP growth holding the other factors constant will decrease public debt by (-4.24491) units this due to that an increase in economic growth is associated by an increase in tax revenues of the state, which leads to reducing the deficit in the public budget or cancel it and thus reduce the need for the state to borrow which leading to a reduction of public debt to GDP ratio. this result is consistent with the results of Waheed (2017), Mah, Mukkudem-Petersen, Miruka and Petersen (2013), Sinha, Arora and Bansal (2011), Swamy,(2015), Bittencourt (2013) and Gargouri and Ksantini (2016).

3.The long -run coefficients results in Table (3) show that unemployment rate (UNE) has a positive and significant impact on public debt in Jordan at 0.0093 level with coefficient value of (12.71306) this means a 1 unit increase in unemployment rate holding the other factors constant will increase public debt by (12.71306) units, this is due to the fact that high unemployment will lead to lower public tax revenues due to the low number of people paying income tax, also, the high unemployment rate would lead to a decrease in the spending of unemployed people and their families, 
leading to a decrease in the value added tax collected by the state. In addition the state has to spend more on unemployment.

4. From Table (3) government current expenditure has a positive and not significant impact on public debt in Jordan, this is due to the fact that the Jordanian government does not use a large proportion of the public debt for current spending purposes, but rather most of the public debt goes to capital spending that generating income and to repay debt and debt service this result consistence with results of Waheed (2017), Mah, Mukkudem-Petersen, Miruka and Petersen (2013).

\subsection{ARDL Short Run and Cointegration (Error correction) Results:}

The results of short run and co-integration are included in the Table (4). 4 maximum lag automatically selected based on Akaike information criteria maximum (AIC). the selected model based on (AIC) is $(0,1,1,0)$ as the best equation. The estimated cointegration equation:

Cointegrating Equation:

$\mathrm{D}(\mathrm{PD})=-0.745358606057 * \mathrm{D}(\mathrm{BD})+0.030961680499 * \mathrm{D}(\mathrm{GDPG})+0.379883434296 * \mathrm{D}(\mathrm{GDPG}(-1))+$ $1.242624115037 * \mathrm{D}(\mathrm{UNE}) \quad-5.321145796924 * \mathrm{D}(\mathrm{UNE}(-1))+5.139447574129 *(\mathrm{PD}-(-3.25597646 * \mathrm{BD}(-1) \quad-$ 4.24490708*GDPG(-1) + 12.71305646*UNE(-1) + 12.03754432*GS(-1) -1.10611332 ) -0.312232041020*CointEq(1) )........

The sign of the coefficient of the cointegration equation (CointEq1) is negative and significant, since its probability is (0.0000) which is less than 5\% percent. Therefore, there is a long run causality running from budget deficit (BD), real GDP growth (GDPG), unemployment rate (UNE) and government current expenditure (GS) to public debt(PD). The estimated coefficient of the cointegration equation CointEq(-1) is $(-0.31223)$ (prob value $=0.000$ ) indicates that the speed of adjustment from short-run disequilibrium toward long-run equilibrium level, particularly 0.31223 percent of short-run errors will be corrected in the long run.

Table (4)ARDL short run and Cointegration

Dependent Variable: PD

\begin{tabular}{|c|c|c|c|c|}
\hline \multicolumn{5}{|c|}{ Cointegrating Form } \\
\hline Variable & Coefficient & Std.Error & tStatistic & Prob. \\
\hline $\mathrm{D}(\mathrm{BD})$ & 0.74536 & 0.155402 & 4.79633 & 0.0003 \\
\hline $\mathrm{D}(\mathrm{GDPG})$ & -0.030962 & 0.165665 & -0.186893 & 0.8546 \\
\hline $\mathrm{D}(\mathrm{GDPG}(-1))$ & -0.379883 & 0.202421 & 1.876703 & 0.0832 \\
\hline D(UNE) & 1.242624 & 0.733346 & 1.694459 & 0.114 \\
\hline $\mathrm{D}(\mathrm{UNE}(-1))$ & 5.32115 & 1.148209 & 4.6343 & 0.0005 \\
\hline $\mathrm{D}(\mathrm{GS})$ & 5.139448 & 2.261107 & 2.272979 & 0.0406 \\
\hline CointEq(-1) & -0.31223 & 0.043658 & -7.15177 & 0 \\
\hline
\end{tabular}

1- The first difference of budget deficit has a positive and significant impact on public debt in Jordan, the coefficient of $\mathrm{D}(\mathrm{BD})$ is $(0.74536)$ and the probability is (0.0003), which shows a positive relationship with public debt in Jordan.

2- The first difference of real GDP growth (D(GDPG) have a negative but not significant impact on public debt and $\mathrm{D}($ GDPG(-1)) have a negative and significant impact on public debt in Jordan in the short run with coefficient values of (-0.379883) and significant level of (0.0832).

3- The first difference of unemployment rate $\mathrm{D}(\mathrm{UNE})$ has a positive but not significant impact on public debt in Jordan in short run while $\mathrm{D}(\mathrm{UNE}(-1))$ has a positive and significant impact on public debt in Jordan with coefficient value of (5.32115) and significant level of (0.0005).

4- The first difference of government current expenditure $D(G S)$ has a positive and significant impact on public debt in Jordan with coefficient value of ( 5.139448) and significant level of ( 0.0406).

\subsection{Autoregressive Distributed Lagged (ARDL) Estimation Results}

The results of the estimated unrestricted ARDL included in Table (5). 4 maximum lag automatically selected based on Akaike information criteria maximum (AIC). the selected unrestricted ARDL model based on (AIC) is $(1,1,2,2,0)$ as the best equation, the estimated equation is:

$\mathrm{PD}=0.691671842375 * \mathrm{PD}(-1)-0.750757838109 * \mathrm{BD}-0.253151384902 * \mathrm{BD}(-1)-0.0147100450581 * \mathrm{GDPG}-$ $0.949323397756 *$ GDPG(-1) $-0.344790937006 *$ GDPG(-2) + 1.24917147794*UNE - 2.51852844621*UNE(-1) + $5.18915024362 * \mathrm{UNE}(-2)+3.71151386147 * \mathrm{GS}-0.341045882033$ 
from Table (5) R-square value is (0.982058) and adjusted $\mathrm{R}$ square value is (0.968256) shows that the econometrics model explain more than $96 \%$ of the change in public debt $\left(\mathrm{MPD}_{2}\right)$ in Jordan and this indicates that the model is fit. The F-Statistic value is (71.1551) and its probability (0.000) indicates that the explanatory variables are jointly significant and are capable of explaining changes in public debt (PD) in Jordan .

Table (5) unrestricted ARDL Results Dependent Variable PD

Model selection method: Akaike info criterion (AIC)

Selected Model: ARDL(1, 1, 2, 2, 0)

\begin{tabular}{|lllll|}
\hline Variable & Coefficient & Std. Error & t-Statistic & Prob. $^{*}$ \\
\hline PD(-1) & 0.691672 & 0.108268 & 6.388525 & 0 \\
\hline BD & -0.75076 & 0.25289 & -2.96872 & 0.0109 \\
\hline BD(-1) & -0.25315 & 0.236 & -1.07268 & 0.3029 \\
\hline GDPG & -0.01471 & 0.241331 & -0.06095 & 0.9523 \\
\hline GDPG(-1) & -0.94932 & 0.217624 & -4.36223 & 0.0008 \\
\hline GDPG(-2) & -0.34479 & 0.249847 & -1.38001 & 0.1909 \\
\hline UNE & 1.249171 & 1.269544 & 0.983953 & 0.3431 \\
\hline UNE(-1) & -2.51853 & 1.622541 & -1.55221 & 0.1446 \\
\hline UNE(-2) & 5.18915 & 1.551286 & 3.345064 & 0.0053 \\
\hline GS & 3.711514 & 2.259528 & 1.642606 & 0.1244 \\
\hline C & -0.34105 & 0.227868 & -1.49668 & 0.1584 \\
\hline R-squared & 0.982058 & Mean dependentvar & 0.914793 \\
\hline AdjustedRsquared & 0.968256 & S.D. dependent var & 0.227487 \\
\hline S.E. of regression & 0.040531 & Akaike infocriterion & -3.26994 \\
\hline Sum squared resid & 0.021356 & Schwarz criterion & -2.73 \\
\hline F-statistic & 71.1551 & Durbin-Watsonstat & 2.060068 \\
\hline Prob(F-statistic) & 0 & & \\
\hline
\end{tabular}

E Views (9) output

\subsection{Residual Diagnostics for Unrestricted ARDL}

The following diagnostic tests (Breusch-Godfrey Serial Correlation LM Test, Heteroskedasticity Test: Breusch-PaganGodfrey and normality test) results show that the model passes the three autocorrelation and heteroskedasticity and normality tests, since their probabilities values are more than $5 \%$.

Table (6)Breusch-Godfrey Serial Correlation LM Test results

\begin{tabular}{|lccc|}
\hline F-statistic & 1.218535 & Prob. F(2,11) & 0.3326 \\
\hline & & Prob. & Chi- \\
Obs*R-squared & 4.352859 & Square(2) & 0.1134 \\
\hline
\end{tabular}

Table (7)Heteroskedasticity Test: Breusch-Pagan-Godfrey

\begin{tabular}{|lccc|}
\hline F-statistic & 0.683118 & Prob. F(10,13) & 0.7237 \\
\hline Obs*R-squared & 8.267203 & Prob.ChiSquare(10) & 0.6028 \\
\hline Scaled explained SS & 1.14338 & Prob.ChiSquare(10) & 0.9997 \\
\hline
\end{tabular}

Table (8) Normality Test

\begin{tabular}{|l|l|}
\hline Jarque-Bera & 1.346802 \\
\hline Probability & 0.509971 \\
\hline
\end{tabular}

\subsubsection{CUSUM Stability Test for the Unrestricted ARDL}

This study used the CUSUM stability test (Cumulative Sum of recursive residuals) which was developed by Brown et al., (1975). If the plot of CUSUM statistic stays within 5\% significance level, then the estimated model is said to be stable (Dritsakis, 2011). figure (1) shows the results of the(CUSUM) Cumulative Sum of Recursive Residuals for 
Unrestricted ARDL. from figure (1) the plot of CUSUM statistics stays within 5\% significant level this means that the public debt (PD) estimated model is stable.

Figure (1) CUSUM Cumulative Sum of Recursive Residuals for Unrestricted ARDL

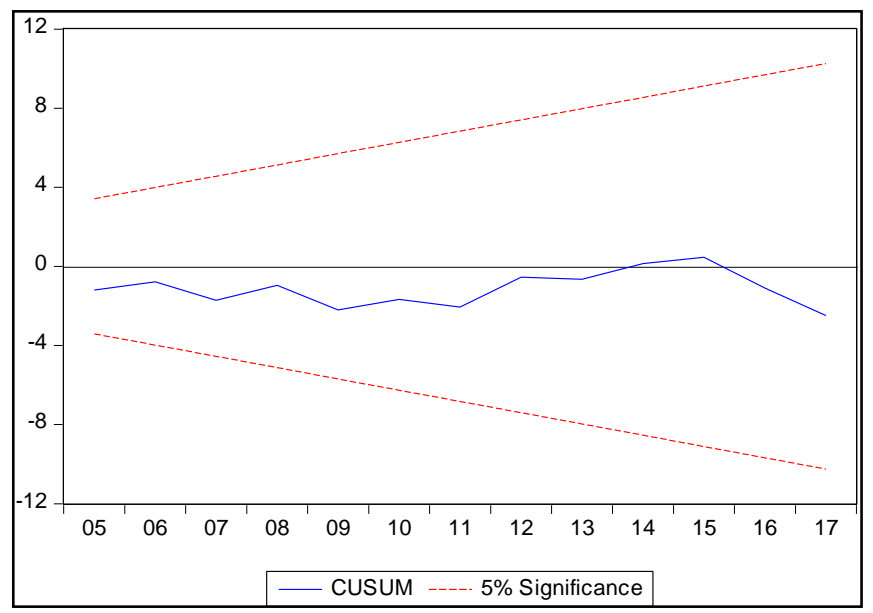

\section{Conclusions:}

The current study investigated the impact of budget deficit (BD), real GDP growth (GDPG), unemployment rate (UNE) and government current expenditure (GS) on public debt in Jordan. the study used annually time series data for the period (1992-2017) and unrestricted and restricted Autoregressive Distributive Lag(ARDL) Approach and ARDL Bound test, to examine the study hypotheses. In addition, Cumulative Sum (CUSUM) of recursive residuals is used to confirm the stability of the estimated model. The study has found the following results:

1- ARDL bound test proven that there is a long run relationship between budget deficit (BD), real GDP growth (GDPG), unemployment rate (UNE), government current expenditure (GS) and public debt in Jordan.

2- The cointegration results show that there is a long run relationship between budget deficit (BD), real GDP growth (GDPG), unemployment rate (UNE), government current expenditure (GS) and public debt in Jordan.

3- The statistical analysis shows that budget deficit (BD) has a positive and significant impact on public debt in Jordan in the short run and the long run, this is because the increase in the budget deficit push the state to borrow to fill the gap in the public budget, which leads to an increase in the public debt on the one hand, on the other hand, the public debt entails the payment of interest or what is known as public debt service, which increases the financial burden on the state.

4. The statistical analysis results show that Real GDP growth (GDPG) has a negative and significant impact on public debt in Jordan in the short run and the long run, this is attributed to the fact that the increase in economic growth leads to an increase in tax revenues of the state, which works to reduce or eliminate the deficit in the public budget and thus lower government borrowing and then decline the public debt.

5. The statistical analysis results show that unemployment rate (UNE) has a positive and significant impact on public debt in Jordan in the short run and the long run, this is attributed to the fact that the increase in unemployment rates leads to lower tax revenues due to the decrease in the number of those paying this tax. In addition, the increase in unemployment rates reduces the expenses of the unemployed and their families, which reduces the amount of the added tax paid. Thus increasing the deficit in the public budget and pushing the government to borrow more which increases the public debt.

6. The long run coefficients show that the government spending has a positive and not significant impact on public debt in Jordan in the long run but it has a positive and significant impact on public debt in Jordan, this is because the Jordanian government does not use large proportions of public debt in current expenditures in long run but it did that in the short run.

Policy Implications: The study concluded that increasing the deficit in the public budget is increasing the public debt. Therefore, the study recommends political decision-makers to work continuously to reduce the deficit in the public budget in order to reduce the public debt. The study concluded that increasing growth in real GDP leads to a reduction in public debt. Therefore, the study recommends policymakers to use all economic policies to maintain high growth rates in real GDP to reduce public debt. 
The study concluded that the increase in unemployment leads to an increase in public debt. Therefore, the study recommends the policy makers to use all policies to reduce unemployment rates in order to reduce the public debt. The study concluded that the current public expenditure in the long term does not have an impact on the increase in public debt while it has a short-term effect. Therefore, the study recommends the policy makers not use public debt for the purpose of public current expenditure in order to reduce public debt.

\section{References}

Barro R. J., (1987)Government Spending, Interest Rates, Prices, and Budget Deficits in the United Kingdom, 17011918, NBER Working Papers from National Bureau of Economic Research, Inc., № 2005.

Bittencourt, M., (2013) Determinants of Government and External Debt: Evidence from the Young Democracies of South America, Economic Research Southern Africa ( ERSA) working paper 341.

Brown, R.L., J. Durbin, and J.M. Evans (1975), Techniques for Testing the Constancy of Regression Relations Over Time, Journal of the Royal Statistical Society, Series B, 37, 149-163.

Dornbusch, R., \& Fisher, S. (1990). Macroeconomics, McGraw Hill Publishing Company, New York.

Dritsakis, N. (2011) Demand for money in Hungary: An ARDL Approach . Review of Economics \& Finance vol. 1, 0116.

Gargouri, T., and Ksantini, M., (2016) The determinants of public debt, The Romanian Economic Journal, No, 59.

Gill, I., and Pinto B., (2005) Public debt in developing countries: has the market based model worked?, World Bank Policy Research Working Paper № 3674.

Gordon, R. J. (2003). M.acroeconomics, ninth edition, Addison Wesley, New York.

Mah, G.; Mukkudem-Petersen, J.; Miruka, C. and Petersen, M. A. (2013). The impact of Government Expenditure on the Greek Government Debt: An Econometric Analysis. Mediterranean Journal of Social Sciences, 4(3), 323 330.

Martin F., (2004) A Positive Theory of Government Debt, Job Market Paper.

McConnel C., Brue S., (1998) Economics: Principles, Problems and Policies,14th ed., Irwin/McGraw.

Nkorol, E., and Kelvin Uko, A., (2016) Autoregressive Distributed Lag (ARDL) cointegration technique: application and interpretation, Journal of Statistical and Econometric Methods, vol.5, no.4.

Pesaran M, H., and Pesaran, B.,(2002) Working with Microfit 4.0: Interactive Econometric Analysis. Oxford University Press.

Pesaran, M. H. and Y. Shin (1999), an autoregressive distributed lag modeling approach to cointegration analysis. In Strom, S. (ed.), Econometrics and Economic Theory in the 20th Century: The Ragnar Frisch Centennial Symposium. Cambridge: Cambridge University Press.

Pesaran, M. H., Shin, Y., \& Smith, R. J. (2001). Bounds testing approaches to the analysis of level relationships. Journal of applied econometrics, 16(3),pp 289-326.

Peseran, M. H., Peseran, B. (1997). Working with Microfit 4.0: Interactive Econometric Analysis, Oxford: Oxford University Press.

Pirtea, M. G., Nicolescu, A., and Mota, P.R., (2013) An empirical study on public debt's determinants: evidence from Romania, Transylvanian Review of Administrative Sciences, No. 38.

Sinha,P., Arora, V., and Bansal, V., (2011) Determinants of Public Debt for middle income and high income group countries using Panel Data regression, Faculty of Management Studies University of Delhi, India, MPRA Paper No. 32079.

Swamy, V., (2015) Government Debt and its Macroeconomic Determinants - An Empirical Investigation, MPRA Paper No. 64106.

Waheed, A., (2017) Determinants of external Debt: a panel data analysis for oil and gas exporting and importing countries, International Journal of Economics and Financial Issues, 2017, 7(1).

Ziesemer T., (2005)Unstable Debt/GDP Dynamics as an Early Warning Indicator, MERIT-Infonomics Research Memorandum series. 